\section{Are corepressors always repressors?}

\author{
Andrea Hessenauer, Martin Laschak, \\ Klaus-Dieter Spindler \\ University of Ulm, General Zoology \\ and Endocrinology, Ulm, Germany
}

\section{Abstract}

In this review we summarize data on paradox actions of corepressors, acting under certain circumstances as activators of transcription. Putative mechanisms, including the role of splice variants, recruitment of coactivators by corepressors and the importance of chromatin structure and hormone response elements are discussed.

\section{Introduction}

The regulation of gene expression by transcriptional activation or repression is a general phenomenon present in all taxa. The mechanisms of these regulations are conserved in evolution. ${ }^{1}$ In bacteria and archaea repressors or activators directly interact with the genes of interest whereas in eukaryotes more indirect mechanisms are evolved consistent with the chromatin environment of the genes, finally leading to a modulation of chromatin structure by enzymatic modifications of the core histone amino-terminal tails. $^{2-4}$ This histone code is an essential feature in the distinct and specific regulation of transcriptional programmes. ${ }^{5}$ It is therefore not surprising that dysregulations in expression and function of these coregulators are connected to various diseases. ${ }^{6}$

In the present review we will mainly deal with corepressors of nuclear receptors (NR) which represent a huge family of proteins characterized by their ability to bind to transcription factors and to recruit various enzymatic complexes like histone deacetylases thus leading to a more compact chromatin and inhibition of transcription. Models of corepressor action, mainly of the two abundant corepressors $\mathrm{NCoR}$ (nuclear receptor co-repressor) and SMRT (silencing mediator of retinoic acid and thyroid hormone receptor) were recently reviewed. ${ }^{7}$ We therefore focus on non-conventional and unexpected actions of corepressors in this review.

\section{Activating actions of corepressors}

Originally corepressors were thought to be recruited to DNA by unliganded nuclear receptors. But in addition to these conventional corepressors, unconventional ones were described which are specifically recruited by liganded nuclear receptors. As a third category multifunctional corepressors were described. ${ }^{7}$ An example of this category is the corepressor hairless, which can be either a conventional corepressor of unliganded thyroid hormone receptor or an unconventional one with the retinoid acid and the vitamin D receptor as well as with the retinoic acid related orphan receptor in an agonistdependent fashion. ${ }^{8}$

As a fourth category of corepressor function it has been demonstrated that otherwise classical corepressors do not repress gene expression but may even lead to an activation. Examples for this action contradictory to their name are summarized in Table 1. This phenomenon was predominantly found for the corepressors SMRT and NCoR interacting with various nuclear receptors but also for different zinc-finger transcription factors. The outcome of the action of these factors obviously depends on the cellular environment, as also demonstrated in Figure 1. In COS-1 cells the androgen-induced transactivation is repressed by NCoR, whereas in the human prostate cancer cell line PC-3 it is increased. In both instances the specific class I and II histone deacetylase inhibitor Trichostatin A (TSA) leads to the expected results, a significant reduction of the inhibition in case of repressor function like in COS-1 cells (Figure 1A) but a significant reduction of the activation exerted by $\mathrm{NCoR}$ in prostate cancer cells (Figure 1B). The same results were also gained in experiments when NCoR is effectively silenced in COS-1 and the two prostate cancer cell lines PC-3 and LNCaP (Figure 2). If NCoR expression is reduced by a specific shRNA the hormone-induced transactivation is increased in COS-1 cells as expected, but reduced in the prostate cancer cell lines. If NCoR is overexpressed there is the classical repression effect in COS-1 cells, but activation in the prostate cancer cell lines (Figure 2A-C).

\section{Possible mechanisms of the rever- sal of corepressor action}

The question arises how these activating functions of corepressors are produced. At least three different modes are possible: i) Splice variants: In addition to the evolutionary gene duplication leading to SMRT and NCoR paralogs, there is also corepressor diversification by mRNA splicing. This leads to a series of corepressor protein variants with distinctive functional differences like distinguishable repression properties and/or recruitment of various transcription factors. $^{21}$ If in a splice variant repression domains (located in the N-terminal and cen-
Correspondence: Klaus-Dieter Spindler University of Ulm, General Zoology and Endocrinology, Albert-Einstein-Allee 11, D - 89069 Ulm, Germany.

Tel.: +49.0.731.5022583 - Fax: +49.0.7315022581 E-mail: klaus-dieter.spindler@uni-ulm.de

Key words: corepressor/coactivator paradox, splice variants, coactivator recruitment, chromatin structure.

Acknowledgements: this work was supported by a grant from the Deutsche Forschungsgemeinschaft (HE 6078) to $\mathrm{AH}$ and the International Graduate School in Molecular Medicine to ML.

Conflict of interest: the authors report no conflicts of interest.

Received for publication: 15 July 2011

Accepted for publication: 22 July 2011.

This work is licensed under a Creative Commons Attribution NonCommercial 3.0 License (CC BYNC 3.0).

(C) Copyright A. Hessenauer et al., 2011

Licensee PAGEPress, Italy

Endocrinology Studies 2011; 1:e8

doi:10.4081/es.2011.e8

tral regions) or CoRNR box motifs (C-terminal, responsible for nuclear receptor binding) are lost or diminished, the repression function of a corepressor might be reduced, completely abolished or even reversed. This was demonstrated for example for an N-terminally truncated $\mathrm{NCoR}$ variant and thyroid hormone receptor action, 18 or for androgen dependent gene expression and SMRT $\beta, 10$ which lacks one of the classical repression domains and the newly described nuclear receptor binding site. ${ }^{22} \mathrm{~A}$ similar effect could also be shown for RAR $\alpha$ dependent gene expression in Jurkat cells; ${ }^{14}$ ii) Recruitment of coactivators by corepressors: Direct interactions of SMRT with the coactivator SRC-1,12 and for NCoR with SRC1, -2 , and -3 were described. ${ }^{23}$ SMRT and SRC-3 bind directly in an estrogen receptor alpha (ER $\alpha$ )-independent way. Estrogen promotes SRC-3 binding to $\mathrm{ER} \alpha$. SMRT is thus recruited to the regulatory regions of the progesterone receptor and the cyclin D1 gene by estradiol. If SMRT is depleted this hormone-dependent gene expression is diminished, demonstrating that SMRT is required for full transcriptional activity of the ER $\alpha$ in breast cancer cells. ${ }^{12}$ In case of $\mathrm{NCoR}$, a trimeric complex consisting of the corepressor, the coactivator SRC and the unliganded thyroid hormone receptor was demonstrated. ${ }^{23}$ The authors guess that the corepressor raises the local concentra- 
Table 1. Activating actions of corepressors.

\begin{tabular}{|c|c|c|c|c|c|c|}
\hline $\begin{array}{l}\text { Transcription } \\
\text { factor }\end{array}$ & Corepressor & $\begin{array}{l}\text { Activation of } \\
\text { transcription }\end{array}$ & $\begin{array}{l}\text { Inhibition of } \\
\text { transcription }\end{array}$ & Cell type & Remarks & References \\
\hline Androgen receptor & $\begin{array}{l}\text { SMRT, DAX-1 } \\
\text { NCoR } \\
\text { NCoR }\end{array}$ & & $\begin{array}{l}+ \\
+\end{array}$ & $\begin{array}{l}\text { HeLa cells } \\
\text { COS-1 cells } \\
\text { HeLa cells }\end{array}$ & $\begin{array}{l}\text { Neither inhibition } \\
\text { nor activation }\end{array}$ & Agoulnik et al., 2003 \\
\hline Androgen receptor & NCoR, SMRT & + & + & $\begin{array}{l}\text { PC-3, LNCaP } \\
\text { COS cells }\end{array}$ & & Laschak et al., 2011 \\
\hline Estrogen receptor & SMRT & + & + & $\begin{array}{l}\text { HeLa, MCF-7 cells } \\
\text { HepG2 cells }\end{array}$ & & Peterson et al., 2007 \\
\hline Estrogen receptor) & SMRT & + & & HeLa, MCF-7 cells & $\begin{array}{l}\text { Cooperative activation } \\
\text { of estradiol dependent } \\
\text { gene expression by the } \\
\text { coactivator SRC-3 and SMRT }\end{array}$ & Karmakar et al., 2010 \\
\hline Glucocorticoid receptor & SMRT & + & + & COS-1 cells & $\begin{array}{l}\text { SMRT shows strong interaction } \\
\text { with agonists and partial agonists }\end{array}$ & Ronacher et al., 2009 \\
\hline Retinoic acid receptor & SMRT $\beta$ & + & + & $\begin{array}{l}\text { Jurkat, NB4-MRAl, U937 cells } \\
\text { COS cells }\end{array}$ & $\begin{array}{l}\text { Ligand-induced transactivation } \\
\text { is influenced. } \\
\text { SMRT } \alpha \text { without effect }\end{array}$ & Coté et al., 2004 \\
\hline $\begin{array}{l}\text { Thyroid hormone } \\
\text { receptor }\end{array}$ & NCoR, SMRT & + & & $\begin{array}{l}\text { Human embryonic } \mathrm{k} \\
\text { idney cells }\end{array}$ & $\begin{array}{l}\text { Negatively regulated genes are } \\
\text { activated, thyroid hormone } \\
\text { abolishes this effect }\end{array}$ & Tagami et al., 1997 \\
\hline $\begin{array}{l}\text { Thyroid hormone } \\
\text { receptor }\end{array}$ & NCoR, SMRT & + & & HeLa, CV-1 cells & $\begin{array}{l}\text { Activation from negative hormone } \\
\text { response elements of TR }\end{array}$ & Berghagen et al. 2002 \\
\hline $\begin{array}{l}\text { Thyroid hormone } \\
\text { receptor }\end{array}$ & $\mathrm{NCOR}$ & + & & & $\begin{array}{l}\text { Basal transactivation at negative T3 } \\
\text { responsive elements is enhanced, } \\
\text { T3 reverses this effect }\end{array}$ & Kim et al., 2005 \\
\hline $\begin{array}{l}\text { Thyroid hormone } \\
\text { receptor }\end{array}$ & $\mathrm{NCOR}$ & + & & $\begin{array}{l}\text { Saccharomyces } \\
\text { cerevisiae }\end{array}$ & $\begin{array}{l}\text { Splice variants of NCoR coactivate } \\
\text { unliganded TR. Thyroid hormone } \\
\text { inhibits this effect }\end{array}$ & Meng et al., 2005 and 2006 \\
\hline $\begin{array}{l}\text { ZHX1 (zinc finger and } \\
\text { homeobox } \\
\text { transcription factor) }\end{array}$ & $\mathrm{BS} 69$ & + & + & $\begin{array}{l}\text { COS-7, CV-1 cells } \\
\text { HEK cells }\end{array}$ & & Ogata-Kawata et al., 2007 \\
\hline
\end{tabular}

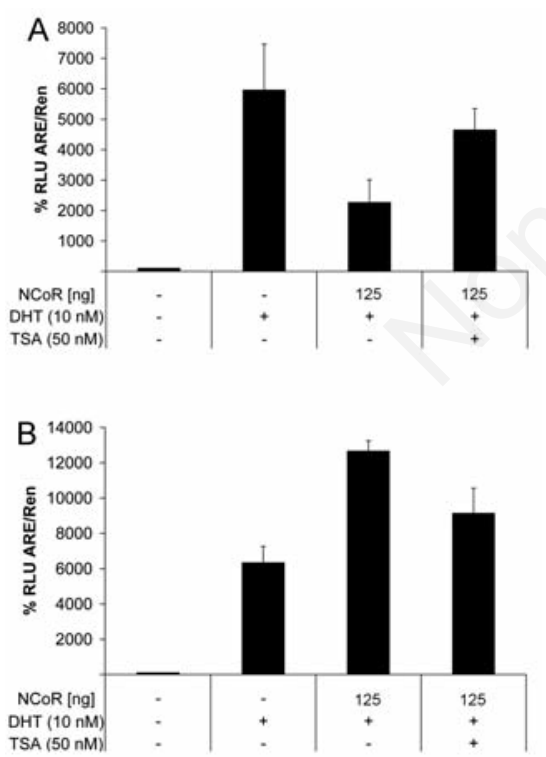

Figure 1. Expression of an androgendependent reporter gene in COS-1 (A) and human prostate cancer cells PC-3 (B) under the influence of dihydrotestosterone (DHT) and the histone deacetylase inhibitor trichostatin A (TSA) with and without overexpression of the corepressor NCoR (own, unpublished results). tion of the coactivator at target gene promotors leading to an enhanced transcriptional activation. For the androgen receptor it might be possible that corepressors recruit histone deacetylases. It has been shown that HDAC1 and HDAC3 are necessary for a full activation of androgen dependent genes. ${ }^{24}$ Our results with the histone deacetylase inhibitor Trichostatin (Figure 1) reducing the NCoR effects also point in this direction; iii) Chromatin structure and hormone response elements: The thyroid hormone receptor can bind to either positive (pHRE) or negative hormone response elements (nHRE). In pHRE corepressors are bound to the nuclear receptor. Upon ligand binding there is a dissociation of this complex and a recruitment of coactivators. In an nHRE the activation of transcription occurs in the absence of hormone when nuclear receptor and corepressor are expected to form a complex. In such a situation a corepressor acts as a coactivator. ${ }^{15,16}$ Berghagen and coworkers mutated the corepressor binding site in the hinge region of the thyroid hormone receptor, inhibiting ligand-independent transcrip- tional activity of the thyroid hormone receptor at an nHRE. Partial protease digestion experiments indicated that the conformation of the thyroid hormone receptor SMRT complex is different whether this complex binds to a pHRE or an nHRE. ${ }^{16}$

The importance of chromatin structure on the effect of a comodulator has also been demonstrated for the coactivator CBP. If this coactivator binds in an euchromatin region it acts as a repressor, but if it binds to heterochromatin it leads to an enhancement of transcriptional activity. ${ }^{25}$

\section{Conclusions}

We here described the phenomenon that a corepressor might act as a coactivator, but there also exist examples for the opposite. For example, the coactivator KAP-1 (also known as TIF1 $\beta$ or TRIM28) can also function as a corepressor, ${ }^{26}$ suggesting that the classification of cofactors as corepressors or coactivators cannot be considered too rigidly. ${ }^{7}$ 

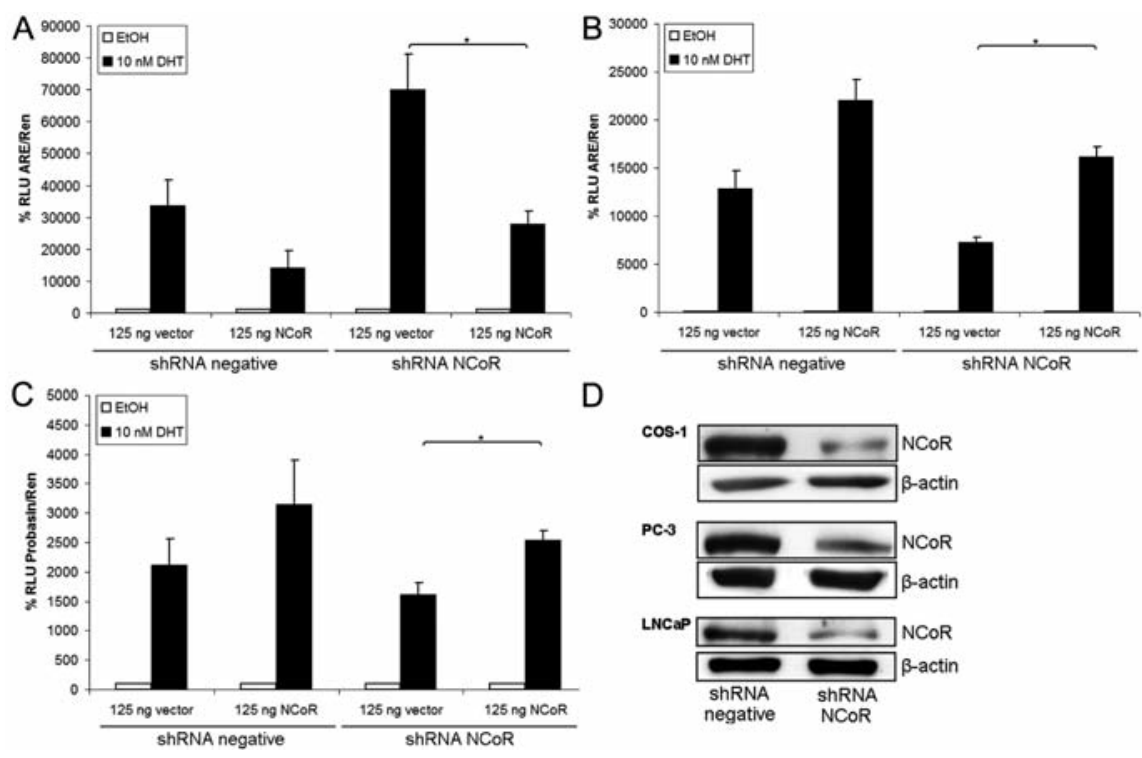

$\mathrm{D}$

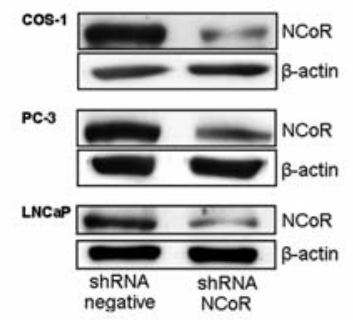

Figure 2. Effect of Flag-NCoR overexpression on AR transactivation in NCoR-silenced COS-1, PC-3 and LNCaP cells. Cells were seeded in 24-well plates and transfected with $400 \mathrm{ng}$ geneticin-resistant shRNA NCoR or shRNA negative as indicated. After $24 \mathrm{~h}$ COS 1 (A) and PC-3 (B) cells were transfected with $200 \mathrm{ng}$ ARE-luc, $62.5 \mathrm{ng}$ pSG5 AR and 80 ng pGL4hR-luc (Ren) in RPMI 1640 containing G $418(500 \mathrm{ng} / \mathrm{mL})$. (C) LNCaP cells were transfected with $200 \mathrm{ng}$ pGL3E-Pro (probasin) and $80 \mathrm{ng}$ pGL4hR luc in RPMI 1640 containing G-418 (500 ng/m). Additionally, $125 \mathrm{ng}$ Flag-NCoR were co transfected as indicated, DNA amount was balanced with pCMX-Gal4. Cells were treated with 10 $\mathrm{nM}$ DHT $24 \mathrm{~h}$ after transfection as indicated, $24 \mathrm{~h}$ later cells were harvested and luciferase activities were determined. Error $b a r=S D, n=3,{ }^{*} P<0.05$. (D) COS $-1, P C-3$ and LNCaP cells were seeded in $25 \mathrm{~cm}^{2}$ flasks and transfected with $4 \mu \mathrm{g}$ shRNA NCoR and shRNA negative respectively. Successfully transfected cells were selected by cultivating the cells in RPMI 1640, $10 \%$ FBS containing G-418 $(500 \mathrm{ng} / \mathrm{mL})$. Cells were harvested and lysed; proteins were separated by SDS-PAGE and transferred to a nitrocellulose membrane by Western blot. Expression of human NCoR and $\beta$-actin was detected by specific antibodies and corresponding HRP-conjugated secondary antibodies. (Own, unpublished results).

\section{References}

1. Payankaulam S, Li LM, Arnosti DN. Transcriptional repression: conserved and evolved features. Curr Biol 2010;20:R764-71.

2. Bhaumik SR, Smith E, Shilkatifard A. Covalent modifications of histones duringdevelopment and disease pathogenesis. J Biol Chem 2007;14:1008-16.

3. Kouzarides T. Chromatin modifications and their function. Cell 2007;128:693-705.

4. Suganuma T, Workman, JL. Crosstalk among histone modifications. Cell 2009; 135:604-07.

5. Strahl BD, Allis CD. The language of covalent histone modifications. Nature 2000;403:41-5.

6. Lonard DM, Lanz RB, O'Malley BW. Nuclear coregulators and human disease. Endocrine Rev 2007;28:575-87.

7. Perissi V, Jepsen K, Glass CK, Rosenfeld MG. Deconstructing repression: evolving models of co-repressor action. Nat Rev Genet 2010;11:109-23.

8. Moraitis AN, Giguerre V, Thompson CC. Novel mechanism of nuclear receptor corepressor interaction dictated by activation function domain 2helix determinants. Mol
Cell Biol 2002;22:6831-41.

9. Agoulnik LU, Krause WC, Bingman III WE, et al. Repressors of androgen and progesterone receptor action. J Biol Chem 2003;278:3113648.

10. Laschak M, Bechtel M, Spindler K-D, Hessenauer A. Inability of NCoR/SMRT to repress androgen receptor transcriptional activity in prostate cancer cell lines. Int J Mol Med 2011. epub ahead.

11. Peterson TJ, Karmakar S, Pace MC, et al. The silencing mediator of retinoic acid and thyroid hormone receptor (SMRT) corepressor is required for full estrogen receptor alpha transcriptional activity. Mol Cell Biol 2007;27:5933-48.

12. Karmakar S, Gao T, Pace MC, et al. Cooperative activation of cyclin D1 and progesterone receptor gene expression by the SRC-1 coactivator and SMRT corepressor. Mol Endocrinol 2010;24:1187-202.

13. Ronacher K, Hadley K, Avenant C, et al. Ligand-selective transactivation and transrepression via the glucocorticoid receptor: role of cofactor interaction. Mol Cell Endocrinol 2009;299:219-31.

14. Coté S, McNamara S, Brambilla B, et al.
Expression of SMRTbeta promotes ligandinduced activation of mutated and wild-type retinoid receptors. Blood 2004;104: 4226-35.

15. Tagami T, Madison LD, Nagaya T, Jameson JL. Nuclear receptor corepressors activate rather than suppress basal transcription of genes that are negatively regulated by thyroid hormone. Mol Cell Biol 1997;17:2642-8.

16. Berghagen H, Ragnhildstveit E, Krogsrud K, et al. Corepressor SMRT functions as a coactivator for thyroid hormone receptor $\mathrm{T} 3 \mathrm{R} \alpha$ from a negative hormone response element. J Biol Chem 2002;277:49517-22.

17. Kim SW, Ho, SC, Hong, SJ, et al. A novel mechanism of thyroid hormone-dependent negative regulation by thyroid hormone receptor, nuclear receptor corepressor (NCoR), and GAGA-binding factor on the rat cD44 promoter. J Biol Chem 2005;280: 1454555.

18. Meng Y, Webb P, Shuen M, et al. E1A and a nuclear receptor corepressor splice variant (N-CoRI) are thyroid hormone receptor coactivators that bind in the corepressor mode. Proc Natl Acad Sci USA 2005;102: 6267-72.

19. Meng X, Arulsundaram VD, Yousef AF, et al. Corepressor/coactivator paradox: potential constitutive coactivation by corepressor splice variants. Nucl Rec Signal 20064:e022.

20. Ogata-Kawata H, Yamada K, Uesaka-Yoshino $\mathrm{M}$, et al. BS69, a corepressor interacting with $\mathrm{ZHX1}$, is a bifunctional transcription factor. FrontBiosci2007; 12:1911-26.

21. Goodson M, Jonas BA, Privalsky ML. Corepressors. Custom tailoring and alterations while you wait. Nucl Rec Signal 2005;3:e03.

22. Varlakhanova N, Snyder C, Jose S, et al. Estrogen receptors recruit SMRT and $\mathrm{N}-\mathrm{CoR}$ corepressors through newly recognized contacts between the corepressor $\mathrm{N}$ terminus and the receptor DNA binding domain. Mol Cell Biol 2010;30:1434-45.

23. Li X, Kimbrel EA, Kenan DJ, McDonnell DP. Direct interactions between corepressors and coactivators permit the integration of nuclear receptor-mediated repression and activation. Mol Endocrinol 2002;16:1482-91.

24. Welsbie DS, Xu J, Chen Y, et al. Histone deacetylses are required for androgen receptor function in hormone-sensitive and castrate-resistant prostate cancer. Cancer Res 2009;69:958-66.

25. Zhao Y, Takeyama K, Sawatsubashi S, et al. Corepressive action of CBP on androgen receptor transactivation in pericentric heterochromatin in a Drosophila experimental model system. Mol Cell Biol 2009;29:1017-34.

26. Rambaud J, Desroches J, Balsalobre A, Drouin J. TIF1ß/KAP-1 is a co-activator of the orphan nuclear receptor NGF1-B/Nur77. J Biol Chem 2009;284:14147-56. 